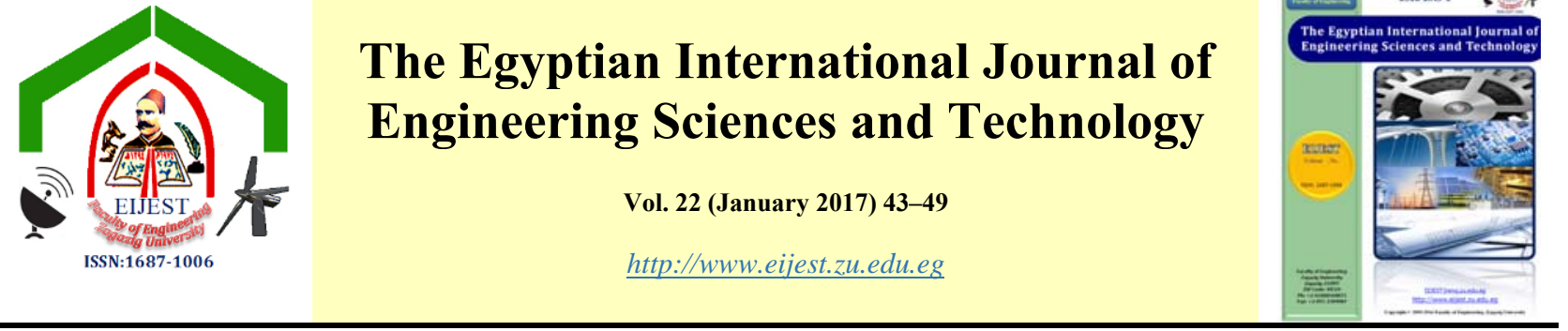

\title{
Effect of Using Weirs Downstream of Parallel Submerged Jets from Opened Multiple Sluice Gates
}

\begin{abstract}
Ahmed M. Nada
Researcher, Hydraulics Research Institute, National Water Research Centre, Egypt

\begin{tabular}{l}
\hline A R T I C L E I N F O \\
\hline Article history: \\
Received: 11 July 2016 \\
Received in revised form: 15 \\
August, 25 September, 9 \\
October, and 30 November \\
2016 \\
Accepted: 4 December 2016 \\
Available online: \\
14 December 2016 \\
\hline
\end{tabular}

Keywords:

Sobek

Weir

Bahr Moues

Tesaa Regulator

A B S T R A C T

The design procedure of regulators recommends the installation of weirs to help in dissipating kinetic energy of water and controlling the hydraulic jump downstream. With the construction of new regulators, the weir downstream the old one is no longer needed and obstruct the water way. These problems appeared downstream Rosetta, Damietta and Tesaa Barrages, for example. The objective of this paper is to study the behavior of weirs downstream of a hydraulic regulator with opened multiple sluice vertical gates. The one-Dimensional Model SOBEK used for simulation of Bahr Moues from $\mathrm{km} 36.0$ to $\mathrm{km} \mathrm{39.5.} \mathrm{The} \mathrm{regulator} \mathrm{considered} \mathrm{for}$ this analysis is Tesaa Regulator which was built in 1832 and is located across Bahr Moues at $\mathrm{km}$ 36.0. Three scenarios were tested; The first scenario suggested changing the dimensions of the existing weir with the existing bed levels. The second one considered dredging the canal to the design levels and keeping the dimensions of the existing weir as is. The second scenario is considered to be more expensive than the first one. It was, however, recommended to adopt the second scenario as it preserves the old regulator which is considered an Islamic archeological structure.
\end{abstract}

(C) 2017 EIJEST. All rights reserved.

\section{1- Introduction}

Weirs are structures constructed across rivers or canals in order to raise the water levels at the upstream and prevent backward water flow for efficient water intake and waterway use. In order to protect hydraulic structures and rivers from the generated energy, the United States Department of the Interior Bureau of Reclamation (USBR) established the Engineering Monograph No. 25 in 1964 for the energy dissipaters of hydraulic structures; the hydraulic jump phenomenon was divided into four forms depending upon Froude numbers. Ten different types of stilling basins and energy dissipaters appropriate for each flow discharge type Peterka [1].

Concerning broad-crested weirs and flows discharges with Froude numbers between 2.5 and 4.5, which accompany huge hydraulic changes, Bhowmik [2] combined energy dissipaters (baffle blocks and end stills). He presented eleven types of energy dissipaters and examined each of their energy dissipation performances [2].

To control the hydraulic jump and enhance its efficiency, sills such as sharp-crested weirs, broadcrested weirs or end sills at the bottoms of waterways are frequently used. The force acting on such a sill in the hydraulic jump rapidly decreases to the minimum as the end point of roller at downstream of the

\footnotetext{
* Corresponding author: Tel. +2-01222642428

E-mail address: ahmedmostafanada@hotmail.com.
} 
hydraulic jump moves upward at a point where it almost overflows a sill. This impact of sills can make the length of the scour risk zone shorter than a normal hydraulic jump phenomenon. Then, as the hydraulic jump becomes shorter and moves further upstream, the force acting on a sill is gradually increases to reach a certain level, Youngkyu, et al. [3]. Since such a rapidly varying flow is characterized as having an uneven velocity distribution, the changes in force upon a sill seem to be happened because of the changes in velocity distribution occurring between the starting points of the hydraulic jump to its end point. Consequently, in a cross-section with unequal velocities, the momentum surges greatly. Theoretically, the hydraulic jump controlled by sills can be interpreted using the momentum theory. However, in the absence of a precise theory of velocity distribution, an accurate quantification can hardly be judged by just relying on theoretical interpretation.

Previous investigations on submerged hydraulic jumps and stilling basins are numerous, [Abdel Alal [4], El Azizi) [5], Govida [6], Hager [7], Negm [8]].

Ali and Mohamed [9] studied the effect of stilling basin shape on submerged jump characteristics. Alireza et al. [10,11] studied the performance of baffle blocks and mean flow in case of submerged hydraulic jump. Chen et al. [12] studied the characteristics of the velocity distribution in a hydraulic jump stilling basin with five parallel offset jets in a twin-Layer configuration. Tiwari [13] and Tiwari and Seema [14] investigated a design of stilling basin with end sill. Mohamed, et al. [15], presented experimental studies aiming to clarify the effect of different sill configurations and arrangements over the stilling basin of Naga Hammadi Barrage, on the flow characteristics such as, length of jump, energy dissipation, length of reverse flow behind the sill and local scour depth.

\section{2- History of Barrages in Egypt}

From the practical point of view, it is usual to install more than one gate in parallel in wide channels. Although, it is a very common circumstance in the irrigation networks, there are very few studies to investigate the flow through parallel gates. The Ministry of Water Resources and Irrigation (MWRI) in Egypt, constructed many barrages along the Nile River, such as Esna, Naga Hammadi, Assuit, Delta, Zefta and Idfena. Some of these Barrages were replaced by other ones to overcome the problem of exceeding the head difference between the upstream and downstream water levels upon gates. The new barrages along the Nile River generate electricity from the head differences.

The following Table 1 describes the existing structures, Abdelazim M. Ali [16].

Table 1 Existing Barrages (with downstream weirs) along the Nile

\begin{tabular}{|c|c|c|c|c|}
\hline \multicolumn{5}{|c|}{ River in Egypt } \\
\hline Name & $\begin{array}{c}\text { Year of } \\
\text { Constructio } \\
\mathrm{n}\end{array}$ & $\begin{array}{c}\text { Location } \\
(\mathrm{km}) \\
\text { From High } \\
\text { Aswan Dam }\end{array}$ & $\begin{array}{c}\text { No. of } \\
\text { Openin } \\
\text { gs }\end{array}$ & $\begin{array}{c}\text { Water } \\
\text { head } \\
(\mathrm{m})\end{array}$ \\
\hline Old Esna & 1908 & 167.85 & 120 & 4 \\
\hline $\begin{array}{c}\text { Old Naga } \\
\text { Hammadi }\end{array}$ & 1930 & 359.45 & 100 & 4.3 \\
\hline Old Assiut & 1902 & 544.75 & 111 & 4.3 \\
\hline $\begin{array}{c}\text { Delta } \\
\text { (Damietta) }\end{array}$ & 1939 & 953.2 & 34 & 3.8 \\
\hline $\begin{array}{c}\text { Delta } \\
\text { Rosetta) }\end{array}$ & 1939 & 953.2 & 46 & 3.8 \\
\hline Zefta & 1903 & 1046.7 & 50 & 4 \\
\hline Edfina & 1951 & 1159.0 & 46 & 2.7 \\
\hline
\end{tabular}

\section{3- Identification of the Problem}

The design procedure recommends using weirs in the downstream of regulators and barrages. The main purposes of using weirs are: -

- During operation, dissipating the kinetic energy of water before discharging it to the main channel.

- During closing of the regulator, the weirs form a stagnant pressure in the downstream which balance the water head upstream.

With the construction of new regulators, the weir downstream the old one become redundant and obstruct the waterway. Rosetta and Damietta Barrages used weirs in their downstream section. Rosetta and Damietta Barrages were built in 1939. Also, Rosetta and Damietta Barrages are considered as Archaeological Structures (Figure 1).

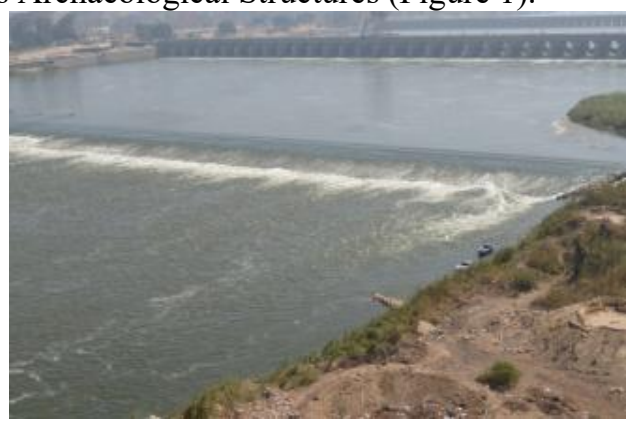

Fig. 1 The weir downstream of Damietta Barrage 
The objective of this paper is to study the behavior of weirs downstream of a hydraulic regulator with opened multiple sluice vertical gates. The oneDimensional Model SOBEK used for simulation of Bahr Moues from km 36.0 to km 39.5.

\section{4- The Study Area}

Bahr Moues intake start at Rayah Tawfiki and is considered the main source of fresh water for Zagazig City covering agriculture, industry, and potable water. In 1832, from the age of Mohamed Ali, a cross regulator was built across Bahr Moues at $\mathrm{km} 36.00$ of Bahr Moues. The regulator called Tesaa Regulator and it was the main reason for establishing Zigzag City. It lies in the center of Zagazig City and gradually become a very crowded and polluted area. For this reason, the Irrigation Sector of Ministry of Water Resources and Irrigation-Egypt, planned to replace the old regulator at $\mathrm{km} 36.00$ by a new one at $\mathrm{km} 39.5$ of Bahr Moues, Hydraulics Research Institute, HRI [17]. The old regulator was kept as an Islamic Archeological Structure. Downstream of the old regulator, there is an old weir. Figure 2 and 3 show the Tesaa Regulator view from the upstream and downstream. Figure 4 shows a satellite image of the layout of Tesaa Regulator.

Upstream of the regulator, there are two branches, Mosalamia canal and Bahr Mashtol. Because of its age and the crowded area, it is required to replace and moves the two intakes to the downstream of the old Tesaa Regulator at km 36.0 and feeding Mosalamia canal and Bahr Mashtol from another two intakes. Figure 5 shows the general layout of the study area. This replacement has positive impact form point of view of social and environmental assessment area.

\section{5- Data Collected}

Figure 6 shows the design discharge required for the study area. Table 2 shows the designed water levels and bed levels.

Table 2 Designed water levels
\begin{tabular}{|l|c|c|}
\hline Structure & $\begin{array}{c}\text { Water Level } \\
(\mathbf{m})\end{array}$ & $\begin{array}{c}\text { Bed Level } \\
(\mathbf{m})\end{array}$ \\
\hline U.s Tesaa Regulator & $\mathbf{( 8 . 7 0 )}$ & $\mathbf{( 5 . 7 0 )}$ \\
\hline D.s Tesaa Regulator & $\mathbf{( 8 . 5 0 )}$ & $\mathbf{( 5 . 7 0 )}$ \\
\hline U.s Weir & $\mathbf{( 8 . 5 0 )}$ & $\mathbf{( 5 . 7 0 )}$ \\
\hline D.s Weir & $\mathbf{( 7 . 5 7 )}$ & $\mathbf{( 4 . 8 0 )}$ \\
\hline U.s New Regulator & $\mathbf{( 7 . 2 5 )}$ & $\mathbf{( 4 . 5 0 )}$ \\
\hline
\end{tabular}

These data were collected from Irrigation sector HRI [17]. Comparison was carried out between the design bed and water levels and the existing situation. The crest level of the weir is (7.66) $\mathrm{m}$ and width $18 \mathrm{~m}$.
Tesaa Regulator consists of seven vents of width 2.5 $\mathrm{m}$ each. A field survey mission measured the cross

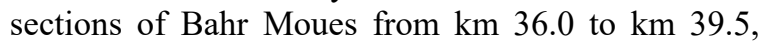
flow discharges, and water levels using DGPS (Differential Global Positioning System), current meters, and electronic levels.

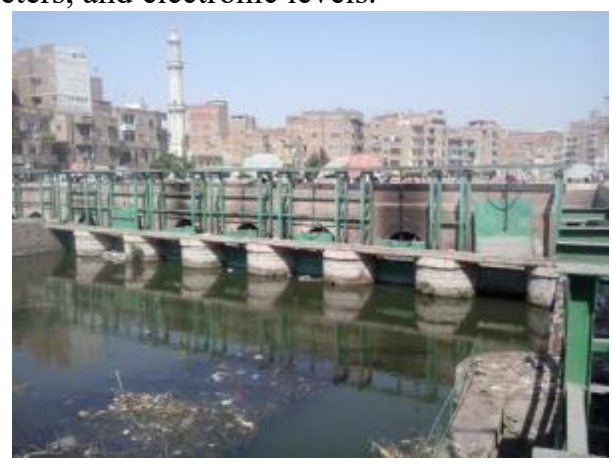

Fig. 2 Upstream view of Tesaa Regulator

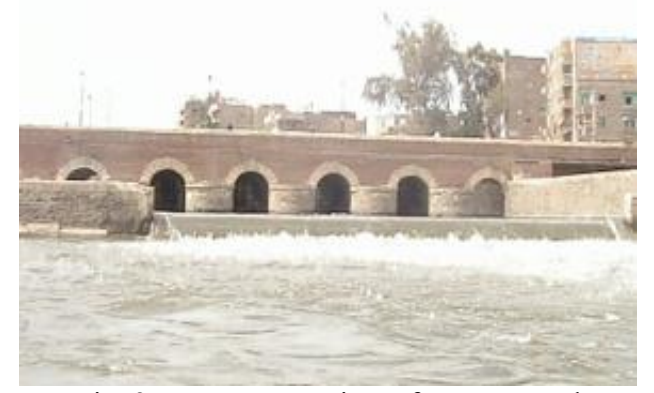

Fig. 3 Downstream view of Tesaa Regulator

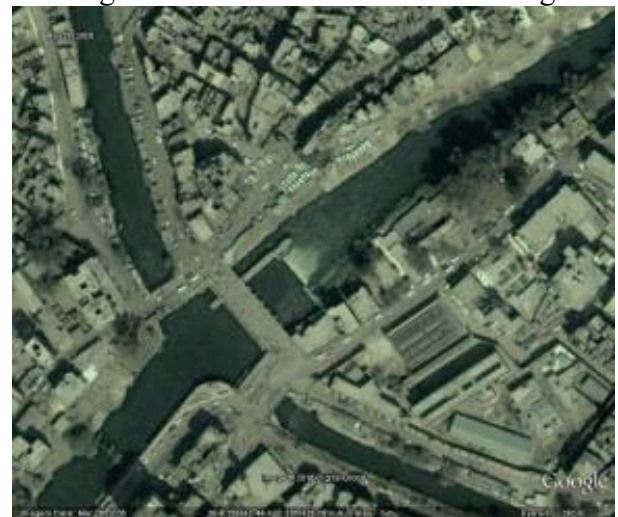

Fig. 4 A satellite image of the layout of Tesaa Regulator

\section{6- Data Analysis}

From the measured and design data, a comparison between longitudinal design and measured bed levels and a comparison between longitudinal design and measured water levels are shown in Figure 7. It shows that the existing bed needs to be dredged one meter to reach the design bed level. Figures 8 and 9 
show the comparison of cross sections at $\mathrm{km} 37$ and km 38 respectively.

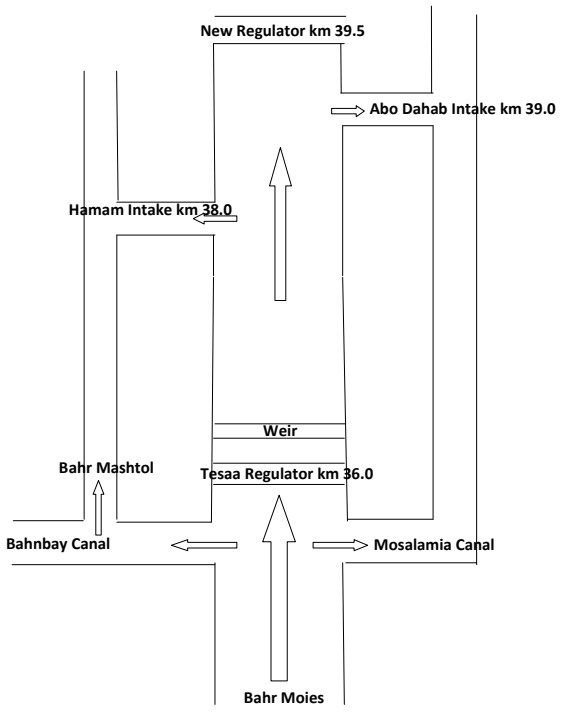

Fig. 5 General layout of the study area

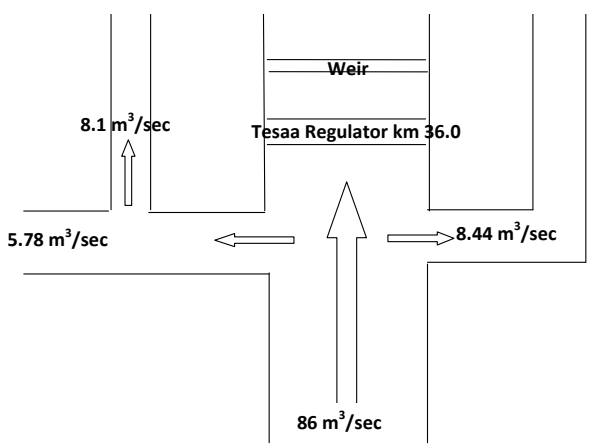

Fig. 6 General layout of the study area flow discharges

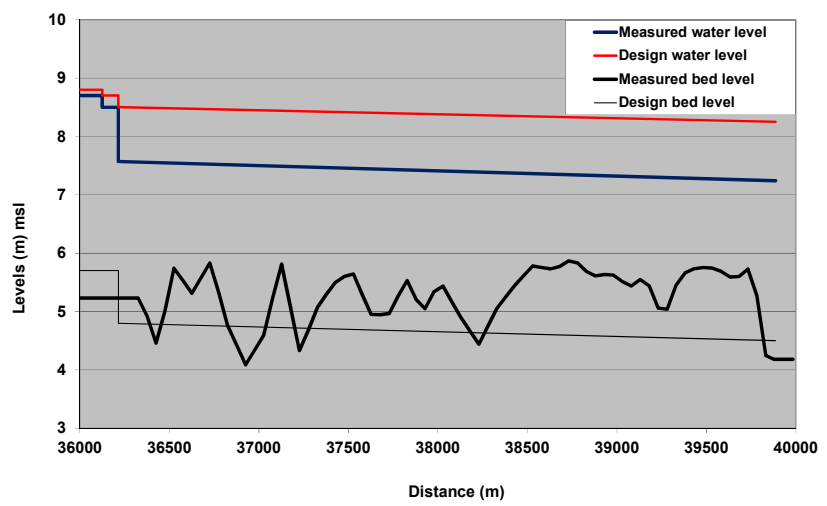

Fig. 7 A comparison between designed bed and water levels to measured bed and water levels

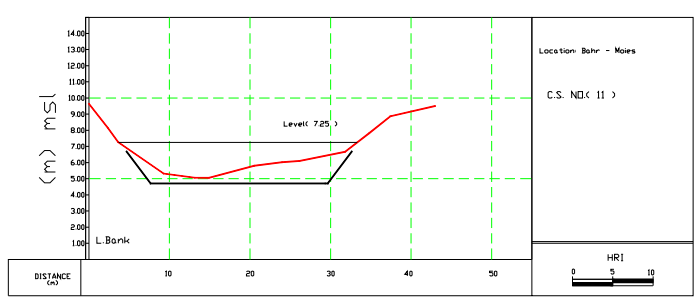

Fig. 8 A comparison between designed and measured cross

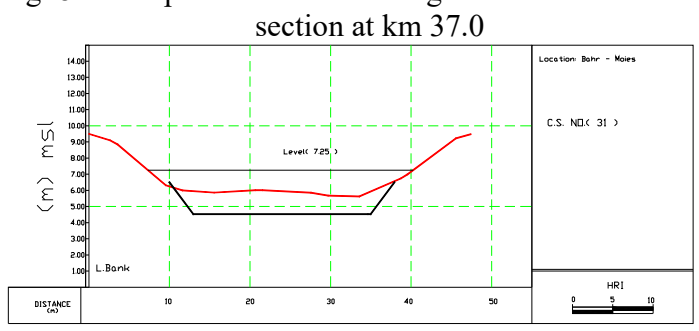

Fig. 9 A comparison between designed and measured cross section at $\mathrm{km} 38.0$

\section{7- Background of Weirs Analysis and computations}

Three types of flow can occur in the case of weir flow. These are free (modular) flow, submerged flow and no flow when water levels are below crest level. If high tail water conditions do affect the flow, the weir is said to be submerged (figure 10). SOBEK, User Manual [18].

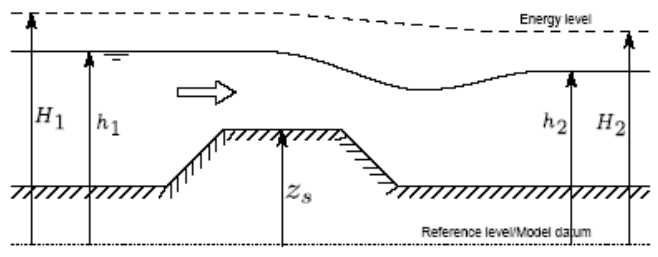

Fig. 10 A sketch of weir flow analysis

Free Flow Weir

$$
\begin{aligned}
& U s=C e \sqrt{\frac{2}{3}} g \sqrt{h 1-Z s} \\
& A f=C w W s \frac{2}{3}(h 1-Z s) \\
& Q=u s A f=C e C w W s \frac{2}{3} \sqrt{\frac{2}{3}} g(h 1-Z s)^{\frac{3}{2}}
\end{aligned}
$$

Submerged Flow Weir

$$
U s=C e \sqrt{2 g(h 1-h 2)}
$$


$A f=C w W s(h 2-Z s)$

$Q=u s A f=C e C w W s \sqrt{2 g(h 1-h 2)}(h 2-Z s)$

where:

$\mathrm{Q}$ : Flow discharge across weir $\left[\mathrm{m}^{3} / \mathrm{s}\right]$

$\mathrm{A}_{\mathrm{f}}$ : Wetted area $\left[\mathrm{m}^{2}\right]$

$\mathrm{C}_{\mathrm{e}}$ : Discharge coefficient [ ]

$\mathrm{C}_{\mathrm{w}}$ : Lateral contraction coefficient [ ]

Ws : Crest width [m]

$\mathrm{g}:$ Acceleration due to gravity $\left[\mathrm{m} / \mathrm{s}^{2}\right](=9: 81)$

$\mathrm{h}_{1}:$ Upstream water level [m]

$\mathrm{h}_{2}$ : Downstream water level [m]

$\mathrm{z}_{\mathrm{s}}:$ Crest level $[\mathrm{m}]$

$\mathrm{u}_{\mathrm{s}}$ : Flow velocity over crest $[\mathrm{m} / \mathrm{s}]$

The weir different formulae are applied when the following conditions occur:

Free Flow Weir

$$
h 1-Z s \succ \frac{3}{2}(h 2-Z s)
$$

Submerged Flow Weir

$$
h 1-Z s \leq \frac{3}{2}(h 2-Z s)
$$

It is clear that bed friction force with the water level gradient force caused by earth gravity have the greatest effect on the water movements. This means that the model should be calibrated according to water level as the follow.

\section{8- Model Setup and Calibration}

A numerical model SOBEK1-D was applied to simulate Bahr Moues. SOBEK is a powerful 1D and 2D tool developed by WL Delft Hydraulics, The Netherlands for flood forecasting, drainage systems, irrigation systems, sewer overflow, and water quality SOBEK, User Manual [18]. Bahr Moues was modeled for the reach between $\mathrm{km} 36$ and $\mathrm{km} 39.5$ using the data collected for cross sections, flow discharges, water levels. The measured -existingcross sections were used to simulate the canal, all existing structures and off takes. A model was built to simulate the existing situation and predict the water levels after replacing the old regulator by a new one.

The numerical model was calibrated and a good agreement between measured and calculated (predicted) water levels was obtained (figure 11). The difference between measured and calculated water levels is within $2.5 \mathrm{~cm}$.

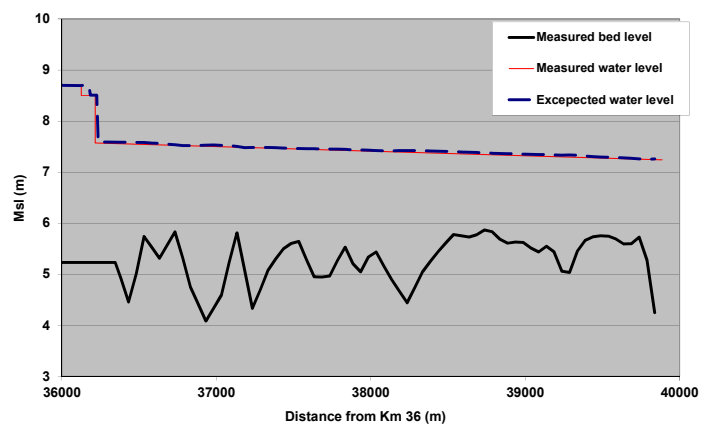

Fig. 11 Model calibration

\section{9- Model Scenarios}

Scenario No (1)

The first scenario considered the case of maximum design flow discharge with existing bed level without dredging. Weir crest level and width were set at (7.65) $\mathrm{m}$ and $20 \mathrm{~m}$ respectively. Gates for both old and new regulators were considered to be fully opened to pass the maximum discharge.

Table 3 shows a comparison between design and predicted water levels for scenario (1). It was found that to comply with the site needs a predicted water level of (9.05) $\mathrm{m}$ upstream of Tesaa Regulator is needed and the designed water level is $(8.80) \mathrm{m}$ which means that this scenario cannot be achieved in reality.this mean that the water levels along Bahr Moues from $\mathrm{km} 0.0$ need to be changed .

Table 3 A comparison between design and predicted water levels

\begin{tabular}{|c|c|c|}
\hline Structure & $\begin{array}{c}\text { Design } \\
\text { water level } \\
(\mathrm{m})\end{array}$ & $\begin{array}{c}\text { Predicted water } \\
\text { level }(\mathrm{m})\end{array}$ \\
\hline $\begin{array}{c}\text { U.s Tesaa } \\
\text { Regulator }\end{array}$ & $(8.80)$ & $(9.05)$ \\
\hline $\begin{array}{c}\text { D.s Tesaa } \\
\text { Regulator }\end{array}$ & $(8.70)$ & $(9.00)$ \\
\hline U.s Weir & $(8.70)$ & $(9.00)$ \\
\hline D.s Weir & $(8.50)$ & $(8.65)$ \\
\hline U.s New Regulator & $(8.25)$ & $(8.25)$ \\
\hline
\end{tabular}

\section{Scenario No (2)}

The second scenario considered the case of maximum design flow discharge with existing bed level without dredging. Weir crest level and width were set at (7.00) $\mathrm{m}$ and $25 \mathrm{~m}$ respectively. Gates for both old and new regulators were considered to be fully opened to pass the maximum discharge. Removing $65 \mathrm{~cm}$ from the crest level could be done manualy in the winter closure.

Table 4 shows a comparison between design and predicted water levels for scenario 2. It was found that the required water level of (8.80) $\mathrm{m}$ upstream of Tesaa Regulator is as the design water level of (8.80) 
$\mathrm{m}$ which means that this scenario could be achieved in reality.

Table 4 A comparison between design and predicted water levels

\begin{tabular}{|c|c|c|}
\hline Structure & $\begin{array}{c}\text { Design water } \\
\text { level }(\mathrm{m})\end{array}$ & $\begin{array}{c}\text { Predicted } \\
\text { water level } \\
(\mathrm{m})\end{array}$ \\
\hline U.s Tesaa Regulator & $(8.80)$ & $(8.80)$ \\
\hline D.s Tesaa Regulator & $(8.70)$ & $(8.70)$ \\
\hline U.s Weir & $(8.70)$ & $(8.70)$ \\
\hline D.s Weir & $(8.50)$ & $(8.50)$ \\
\hline U.s New Regulator & $(8.25)$ & $(8.25)$ \\
\hline
\end{tabular}

\section{Scenario No (3)}

The third scenario considered the case of maximum design flow discharge with dredging the existing bed level to the design level. Weir crest level and width were set at (7.65) $\mathrm{m}$ and $20 \mathrm{~m}$ respectively (the weir was left as it). Gates for both old and new regulators were considered to be fully opened to pass the maximum discharge.

Table 5 shows a comparison between design and predicted water levels for scenario 3. It was found that the required water level of (8.80) m upstream of Tesaa Regulator is as the design water level of (8.80) $\mathrm{m}$ which means that this scenario could be achieved in reality.

Table 5 A comparison between design and predicted water levels for scenario (3)

\begin{tabular}{|l|c|c|}
\hline Structure & $\begin{array}{c}\text { Design water level } \\
(\mathrm{m})\end{array}$ & $\begin{array}{c}\text { Predicted } \\
\text { water level } \\
(\mathrm{m})\end{array}$ \\
\hline U.s Tesaa Regulator & $(8.80)$ & $(8.80)$ \\
\hline D.s Tesaa Regulator & $(8.70)$ & $(8.70)$ \\
\hline U.s Weir & $(8.70)$ & $(8.70)$ \\
\hline D.s Weir & $(8.50)$ & $(8.50)$ \\
\hline U.s New Regulator & $(8.25)$ & $(8.25)$ \\
\hline
\end{tabular}

\section{0- Summary of Scenarios Results and Comments}

Three scenarios were tested using a 1D SOBEK numerical model. The governing factor was the required water level of (8.80) $\mathrm{m}$ upstream of Tesaa Regulator as it is the design water level. The first scenario of existing bed levels and weir dimensions was not practical as the predicted water level was (9.05) $\mathrm{m}$ upstream of Tesaa Regulator which is higher than the design level. The other two scenarios managed to pass water through Bahr Moues without exceeding the design parameters. The first one is changing the dimensions of the existing weir to be of crest level (7.00) m and width $25 \mathrm{~m}$. removing $65 \mathrm{~cm}$ from the crest level could be done manualy in the winter closure. The second scenario is dredging the bed levels to the design levels which is quiet expensive. This needs dredging equipment to work from $\mathrm{km} 36.00$ to $\mathrm{km} 39.50$ and transporting the disposal material to other places.

The author suggests the second scenario of dredging and keeping the dimensions of the existing weir for the sake of conservation of Islamic Archeological Structure.

\section{1- Conclusions and Recommendations}

Tesaa Regulator is located across Bahr Moues at km 36.0 which was built in 1832 . Replacing the old Tesaa regulator by a new one downstream of it necessitates solving the problem of the weir obstruction.

Bahr Moues was modelled from $\mathrm{km} 36$ to $\mathrm{km} 39.5$ using the data collected of cross sections, flow discharges, water levels. The measured (existing) cross sections were used to simulate the canal, all existing structures and off takes. A numerical model was used to simulate the existing situation and predict the water levels after replacing the old regulator by a new one. A numerical model was calibrated and a good agreement between measured and calculated (predicted) water levels was obtained.

Two successful scenarios for passing water through Bahr Moues were identified, the first one is changing the dimensions of the existing weirs with the existing bed levels and the second is dredging the canal bed to the design levels and keeping the dimensions of the existing weir. The second scenario is considered to be more expensive than the first one. The author considers the location of old Tesaa regulator at the middle of Zagazig City environmentally concern so the author suggests the second scenario for the sake of conservation of Islamic Archeological Structure.

It is recommended to clarify this impact in the future design structure of the stilling basin of the regulators.

\section{Acknowledgment}

Gratitude is due to my colleagues at the HRI for providing the hydrographic, bathymetric survey data and the available data related to the study area.

\section{References}

[1] Peterka, A.J. (1964), "Hydraulic Design of Stilling Basins and Energy Dissipators"; A Water Resources Technical Publication Engineering Monograph No. 25; United States Department of the Interior Bureau of Reclamation (USBR): Washington, DC, USA.

[2] Bhowmik, G.N. (1971), "Hydraulic Jump Type Stilling Basins for Froude Number 2.5 to 4.5”; Report of Investigation 67; Illinois State Water Survey: Champaign-Urbana, IL, USA.

[3] Youngkyu Kim, Gyewoon Choi, Hyoseon Park and Seongjoon Byeon (2015), "Hydraulic Jump and Energy Dissipation with Sluice Gate"; Water 2015, 
Vol. 7, pp.5115-5133; doi:10.3390/w7095115, ISSN 2073-4441.

[4] Abdel Alal, G.M. (2004), "Modeling of Rectangular Submerged Hydraulic Jumps", Alexandria Engineering Journal, Vol. 43, No. 6, pp. 65-873.

[5] El-Azizi, I. (1985), "A Study of Submerged Hydraulic Jump Stilling Basins of Low Head Irrigation Structures", M.Sc. Thesis, Faculty of Engineering, Ain Shams University, Egypt.

[6] Govinda Rao, N.S. and Rajaratnam, N. (1963), "The Submerged Hydraulic Jump", Journal of Hydraulic Div., Vol. 89, No. HY1, pp. 139-163.

[7] Hager, W.H. (1992), "Energy Dissipators \& Hydraulic Jumps", Kluwer Academic publication, Dordrecht, The Netherlands, pp. 151-173.

[8] Negm A.M. (1995), "Free and Submerged Flow Below Sluice Gate With Sill", in Advances in Hydroscience and Engineering, Vol.2, Part A, (Ed. Chinese Hydraulic Engineering Society, CHES and International Research and Training Center on Erosion and Sedimentation, IRTCES), Proceedings of Second Int. Conf. on Hydro-Science and Engineering, ICHE95, 22-26 March 1995, Tsinghua University Press, Beijing, China, pp. 283-300.

[9] Ali, A.M., Mohamed, Y.A., (2010), "Effect of Stilling Basin Shape on the Hydraulic Characteristics of the Flow Downstream Radial Gates". AEJ, 49, 393-400

[10] AlirezaHabibzadeh, Mark R. Loewen, and NallamuthuRajaratnam (2012), "Performance of Baffle Blocks in Submerged Hydraulic Jumps". J. Hydraul. Eng., 138(10), 902-908.

[11] AlirezaHabibzadeh, Mark R. Loewen, and NallamuthuRajaratnam (2014), "Mean Flow in a Submerged Hydraulic Jump with Baffle Blocks", J. Eng. Mech., 140(5), 04014020.

[12] Chen, J. G., Zhang, J. M., Xu, W. L., and Peng, Y., (2014), "Characteristics of the Velocity Distribution in a Hydraulic Jump Stilling Basin with Five Parallel Offset Jets in a Twin-Layer Configuration.", J. Hydraul. Eng., Vol. (140), No. (2), pp. 208-217.

[13] Tiwari, H.L. (2013), "Design of Stilling Basin with Impact Wall and End Sill", International Research Journal of Resent Sciences, 2(3), 59-63.
[14] Tiwari, H.L. and TiwariSeema (2013), "Design of Stilling Basin Models with Intermediate Sill". Journal of Science, Technology and Management, 2(4), pp. 66-71.

[15] Mohamed, Y.A., Saleh, Y.K, and Ali, A.M., (2015), "Studying the Effect of Different Configurations and Positions of Sill Over Stilling Basin on Flow Characteristics Behind Radial Gate, (CASE STUDY: NAGAA HAMMADI REGULATOR)", Journal of Engineering Sciences, Assiut University, Vol. (43), No. (3), pp.311 - 329, May 2015.

[16] Abdelazim M. Ali, (2010) "A Hybrid Approach to Improve the Design of Stilling Basin" Produced by the Nile Basin Capacity Building Network (NBCBNSEC) office.

[17] Hydraulics Research Institute (2008) Report No. 106, "Study of Design Cross Section of Bahr Moues from $\mathrm{km} 36.00$ to $\mathrm{km} \mathrm{39.50".}$

[18] Deltaress, (2015)" Sobek User Manual", the Netherlands.

\section{Notations}

Q: Flow discharge across weir $\left[\mathrm{m}^{3} / \mathrm{s}\right]$

$\mathrm{A}_{\mathrm{f}}$ : Wetted area $\left[\mathrm{m}^{2}\right]$

$\mathrm{C}_{\mathrm{e}}$ : Discharge coefficient [_]

$\mathrm{C}_{\mathrm{w}}$ : Lateral contraction coefficient [ $]$

Ws: Crest width [m]

$\mathrm{g}$ : Acceleration due to gravity $\left[\mathrm{m} / \mathrm{s}^{2}\right](=9.81)$

$\mathrm{h}_{1}$ : Upstream water level [m]

$\mathrm{h}_{2}$ : Downstream water level [m]

$\mathrm{z}_{\mathrm{s}}$ : Crest level [m]

$\mathrm{u}_{\mathrm{s}}$ : Flow velocity over crest $[\mathrm{m} / \mathrm{s}]$

\section{Abbreviations}

USBR : United States Department of the Interior Bureau of Reclamation

HRI : Hydraulics Research Institute

MWRI: Ministry of Water Resources and Irrigation

msl : Mean Sea Level

DGPS: Differential Global Positioning System 